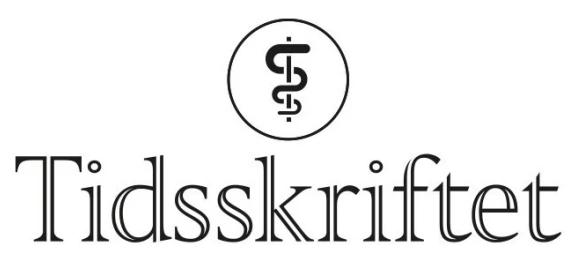

DEN NORSKE LEGEFORENING

\title{
Nummen hake
}

\author{
KORT KASUISTIKK
}

\section{FREDRIK EIKA}

eikafredrik@gmail.com

Medisinsk avdeling

Diakonhjemmet Sykehus

Fredrik Eika er lege i spesialisering i indremedisin.

Forfatteren har fylt ut ICMJE-skjemaet og oppgir ingen interessekonflikter.

\section{JOHANNA ELISABETH RYKKE BERSTAD}

Avdeling for øre-, nese- og hals

Oslo universitetssykehus, Rikshospitalet

Johanna Elisabeth Rykke Berstad er spesialist i oralkirurgi og i oralmedisin og er overtannlege.

Forfatteren har fylt ut ICMJE-skjemaet og oppgir ingen interessekonflikter.

\section{Sykdomsprosesser i underkjeven kan debutere med ensidig nummenhet på leppen og haken. Symptomene kan i sjeldne tilfeller være beskjedne og derfor bli oversett av klinikere og pasienter. Kasuistikken illustrerer et slikt tilfelle og noen diagnostiske betraktninger om tilstanden.}

En mann i 7o-årene kontaktet lege på grunn av spontant tilkommet nummenhetsfølelse på høyre side av haken og høyre del av underleppen. Han hadde ingen andre nevrologiske symptomer, ingen B-symptomer og var ellers i god form. Ved palpasjon av underkjeven fant man svak ømhet over hakens høyre side og ved foramen mentale. Tenner og tannkjøtt fremsto som normale. Pasienten var afebril og med senkningsreaksjon, C-reaktivt protein (CRP) og leukocyttall i normalområdet. På mistanke om cerebral hendelse ble det utført CT-caput, som viste normale funn.

Symptomet ga mistanke om lokal påvirkning av nervus mentalis, som gir sensibilitetsutfall på haken (figur 1) (1). Pasienten ble henvist til poliklinisk CT av ansiktsskjelettet, der man så en lytisk prosess i høyre mandibula, som protruderte gjennom en utvidet foramen mentale (figur 2). Jevne kortikalkonturer uten omkringliggende fettvevsreaksjon ga primært mistanke om tumor. Abscess kunne ikke helt utelukkes, da tannrotinfeksjoner kan ha lignende utseende. Disse infeksjonene gir imidlertid oftest mindre periapikale abscesser. 


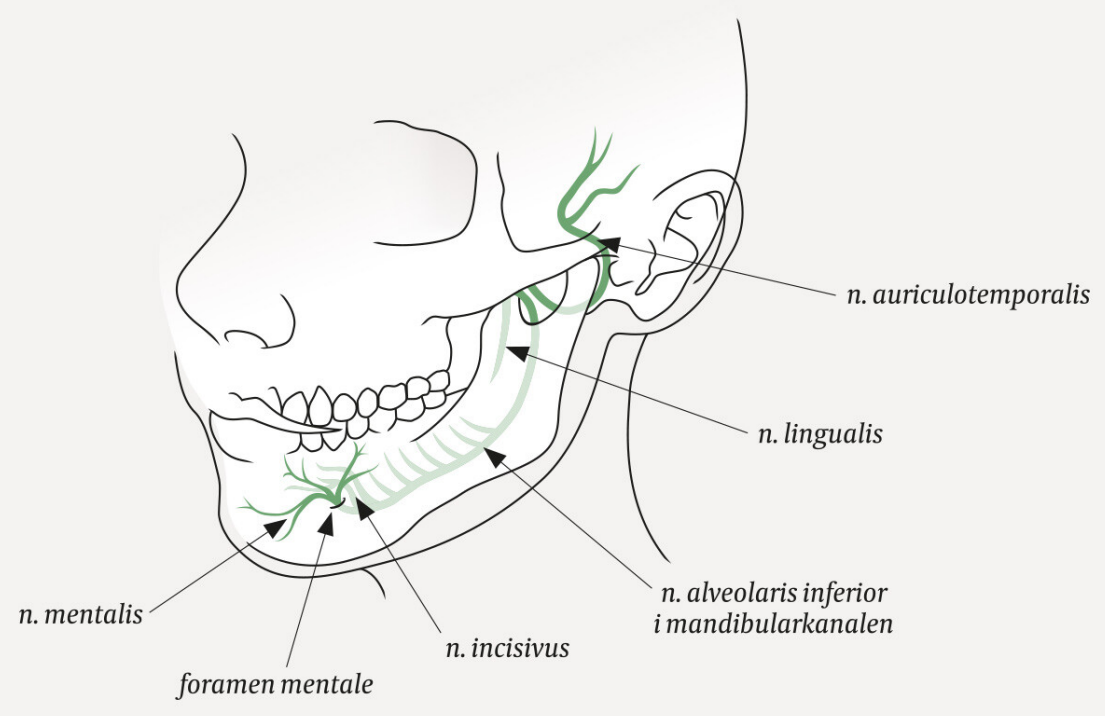

Figur 1 Nervus mentalis er en avgreining av nervus alverolaris inferior, som stammer fra nervus trigeminus sin tredje gren. Nerven passerer gjennom mandibularkanalen i underkjeven og ut av foramen mentale, der den innerverer hud på hake og underleppe på ipsilateral side (1). 
Sectra Reconstruction $\checkmark$

$120 \mathrm{kV}$

Figur 2 CT ansiktsskjelett. Aksialplan. Lytisk prosess i høyre mandibula med bløtdelskomponent som protruderer gjennom en utvidet foramen mentale.

Grunnet bekymring for mulig kreftsykdom ble pasienten henvist til et pakkeforløp ved ørenese-hals-dagavdeling for diagnostisk avklaring. I mellomtiden oppsøkte pasienten tannlege, som fant normale ekstraorale, intraorale og periodontale forhold.

Panoramarøntgen (OPG) viste en velavgrenset radiolusens apikalt om tann 44, som ga mistanke om apikal cyste. Tannlegen anbefalte at pasienten ble utredet videre på sykehus.

På sykehuset supplerte man med CT toraks-abdomen-bekken, som var uten malignitetssuspekte forandringer. Pasienten ble henvist til kjevekirurg for biopsi. Ved intraoral tilgang tømte det seg tyktflytende puss ved perforasjon av foramen mentale. Tann 45 ble fjernet, og man fant en stor pussfylt benkavitet. Mikrobiologisk dyrkning viste oppvekst av Streptococcus oralis og Actinomyces odontolyticus, begge sensitive for 
klindamycin og penicillin. Histopatologi viste nekrotisk benvev med markert kronisk betennelse, men ingen maligne celler. De mikroskopiske funnene passet med det klinisk inntrykket av akutt osteomyelitt utgående fra tann 45.

Ny granskning av panoramarøntgen tatt i 2010 og 2016 viste antydning til apikal radiolusens på tann 44 som kunne gi mistanke om at infeksjonen hadde utgått fra denne tannen. Tann 45 hadde imidlertid en anatomisk sentral plassering uten tydelig avgrensning til den osteolytiske prosessen. På rotspissen hadde tann 45 også påleiring (sklerotiserende apikal periodontitt) som kunne tyde på en kronisk infeksjon i denne tannen. I fravær av andre kliniske funn som økt mobilitet og perkusjonsømhet av tenner, men utfall av sensibilitet i området, ble dette røntgenfunnet avgjørende. Man antok at tann 45 mest sannsynlig var årsak til infeksjonen, og tannen ble fjernet.

Ved klinisk kontroll fire uker senere var pasienten fortsatt nummen i samme område, men det var pen intraoral tilheling. Videre plan innebar 4-6 uker med antibiotikabehandling og rotfylling av de tilgrensende tennene ( 44 og 46 ).

\section{Diskusjon}

Nummen hake kjennetegnes ved sensibilitetsutfall på hake og hud/slimhinne på nedre leppe, og kan være ledsaget av smerter, hovent tannkjøtt, løse tenner eller smerter. I internasjonal litteratur omtales gjerne symptombildet som numb chin syndrome eller mental nerve entrapment $(\mathbf{1}, \mathbf{2})$.

Nummen hake skyldes utfall av sensibilitet i innervasjonsområdet til hele eller deler av nervus alveolaris inferior. Mulige årsaker er blant annet traume, tannprosedyrer, småkirurgi på leppen, periapikal tanninfeksjon, akutt eller kronisk osteomyelitt sekundært til infeksjon i tenner og deres støttevev, metastatisk kreftsykdom eller primære tumorer eller cyster i kjeven (1ํ). Infeksiøse, inflammatoriske og immunologiske årsaker inkluderer humant immunsviktvirus (HIV), borreliose, sarkoidose, systemisk lupus erythematosus, temporalisarteritt og andre vaskulitter (11). Symptomene kan også forårsakes av osteonekrose i kjeven knyttet til bruk av bisfosfanater (3).

Primære maligne tumorer eller metastaser til kjeven er en sjelden årsak til nummen hake som klinikere bør være klar over (4). I en oversiktsartikkel over 16 studier som involverte 136 pasienter med malignitetsrelatert nummen hake, var brystkreft den hyppigst assosierte maligniteten (40,4\%), fulgt av lymfom (20,5\%), prostatakreft (6,6\%) og leukemi (5,1\%) (5). At symptomene kan minne om tannsmerter, osteomyelitt, kjeveleddsplager eller trigeminusnevralgi, kan forsinke diagnosen.

Kasuistikken illustrerer et uvanlig tilfelle av osteomyelitt med diffuse symptomer, der kliniske og radiologiske funn initialt ikke ga mistanke om infeksjon. Dette resulterte i en unødvendig helkropps-CT i forkant av undersøkelse hos kjevekirurg og bekymringer hos pasienten.

Mange med nummen hake vil oppsøke tannlege først, og diagnostiske betraktninger er viktig å kjenne til for denne yrkesgruppen. Som kasuistikken illustrerer kan tverrfaglig samarbeid mellom leger, tannleger og kjevekirurg være viktig i utredning av tilstanden. Skader på $\mathrm{n}$. alveolaris inferior tilheler som regel spontant $(\underline{6}, 7$. .). Pasientens sensibilitet $\mathrm{i}$ leppe og hakehud er nå normalisert.

Pasienten har gitt samtykke til at artikkelen blir publisert.

Takk til Radiologisk avdeling ved Diakonhjemmet Sykehus for hjelp med figur.

Artikkelen er fagfellevurdert. 
1. Smith RM, Hassan A, Robertson CE. Numb Chin Syndrome. Curr Pain Headache Rep 2015; 19: 44. [PubMed][CrossRef]

2. Assaf AT, Jürgens TP, Benecke AW et al. Numb chin syndrome: a rare and often overlooked symptom. J Oral Facial Pain Headache 2014; 28: 80-9o. [PubMed][CrossRef]

3. He L, Sun X, Liu Z et al. Pathogenesis and multidisciplinary management of medication-related osteonecrosis of the jaw. Int J Oral Sci 2020; 12: 30. [PubMed][CrossRef]

4. D'Silva NJ, Summerlin DJ, Cordell KG et al. Metastatic tumors in the jaws: a retrospective study of 114 cases. J Am Dent Assoc 2006; 137: 1667-72. [PubMed][CrossRef]

5. Galán Gil S, Peñarrocha Diago M, Peñarrocha Diago M. Malignant mental nerve neuropathy: systematic review. Med Oral Patol Oral Cir Bucal 2008; 13: E616-21. [PubMed]

6. Alling CC. Dysesthesia of the lingual and inferior alveolar nerves following third molar surgery. J Oral Maxillofac Surg 1986; 44: 454-7. [PubMed][CrossRef]

7. Hillerup S, Stoltze K. Lingual nerve injury in third molar surgery I. Observations on recovery of sensation with spontaneous healing. Int J Oral Maxillofac Surg 2007; 36: 884-9. [PubMed][CrossRef]

Publisert: 7. februar 2022. Tidsskr Nor Legeforen. DOI:10.4045/tidsskr.21.016o

Mottatt 26.2.2021, første revisjon innsendt 17.6.2021, godkjent 8.10.2021.

Publisert under åpen tilgang CC BY-ND. Lastet ned fra tidsskriftet.no 26. april 2023. 